\title{
Experiences of stigma among hepatitis B and C patients in Rawalpindi and Islamabad, Pakistan
}

\author{
I. Rafique, ${ }^{1}$ M.A.N. Saqib, ${ }^{1}$ S. Siddiqui, ${ }^{2}$ M.A. Munir, ${ }^{1}$ H. Qureshi, ${ }^{1}$ N. Javed, ${ }^{1}$ S. Naz and I.Z. Tirmazi ${ }^{3}$
}

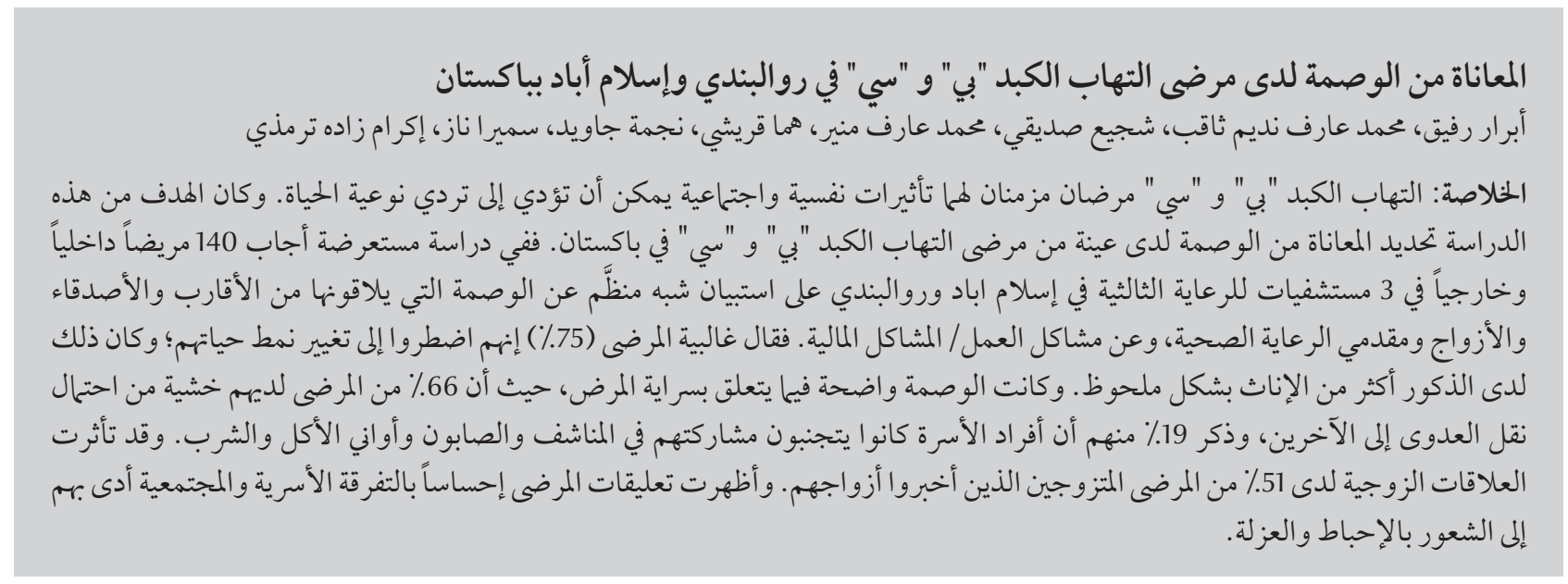

ABSTRACT Hepatitis B and C are chronic diseases with mental and social impacts which can result in poor quality of life. The aim of this study was to determine the experiences of stigma in a sample of hepatitis B- and C-positive patients in Pakistan. In a cross-sectional study, 140 inpatients and outpatients from 3 tertiary-care hospitals in Islamabad and Rawalpindi answered a semi-structured questionnaire about stigma experienced from relatives, friends, spouse and health-care providers, and about work/financial problems. The majority of patients (75\%) said they had had to change their lifestyle, and significantly more were males than females. Stigma was marked in terms of disease transmission, with $66 \%$ of patients fearing that they could transmit the infection to others; $19 \%$ said that family members avoided sharing towels, soap and eating and drinking utensils. Marital relationships were affected for $51 \%$ of married patients who had told their spouse. Patients' comments showed a sense of family and societal discrimination resulting in feelings of disappointment and isolation.

\section{Expériences de stigmatisation chez des patients atteints d'hépatite B et C à Rawalpindi et Islamabad (Pakistan)}

RÉSUMÉ L'hépatite B et C sont des maladies chroniques qui ont des répercussions mentales et sociales susceptibles d'entraîner une mauvaise qualité de vie. L'objectif de la présente étude était des dégager les expériences de stigmatisation au sein d'un échantillon de patients positifs pour l'hépatite B et C au Pakistan. Dans une étude transversale, 140 patients hospitalisés ou consultant dans les services de soins externes de trois hôpitaux de soins tertiaires à Islamabad et Rawalpindi ont répondu à un questionnaire semi-structuré portant sur la stigmatisation infligée par les parents, les amis, le conjoint et les prestataires de soins de santé, et sur les problèmes professionnels/financiers. La majorité des patients (75\%) ont déclaré qu'ils avaient dû changer de mode de vie et la proportion d'hommes était supérieure à celle des femmes. La stigmatisation était marquée pour la transmission de la maladie, avec $66 \%$ des patients craignant de transmettre l'infection à d'autres personnes ; $19 \%$ ont indiqué que les membres de leur famille évitaient de partager les serviettes de toilette, le savon, la vaisselle et les couverts. Les relations conjugales étaient affectées chez 51 \% des patients mariés qui avaient informé leur conjoint. Les commentaires des patients font état d'une certaine discrimination familiale et sociale à l'origine de sentiments de désarroi et d'isolement.

'Pakistan Medical Research Council, Islamabad, Pakistan (Correspondence to M.A.N. Saqib: arif289@gmail.com). ${ }^{2}$ Pakistan Institute of Medical Sciences, Islamabad, Pakistan. ${ }^{3}$ Liver Clinic, Federal Government Services Hospital, Islamabad, Pakistan.

Received: 02/01/14; accepted: 08/04/14 


\section{Introduction}

Hepatitis B and C are major causes of chronic liver disease leading to cirrhosis and hepatocellular carcinoma (1). Because the hepatitis $B$ virus (HBV) and $\mathrm{C}$ virus (HCV) spread through blood and body secretions, including sexual routes, patients may be considered dirty or immoral (2). Stigma is defined as a "sign of social unacceptability: the shame or disgrace attached to something regarded as socially unacceptable" (3) and is a term used by psychologists and sociologists when "elements of labelling, stereotyping, separation, status loss, and discrimination occur together in a power situation that allows them" (4). Stigmas related to hepatitis B and $\mathrm{C}$ infection include isolation from society, problems with close personal relationships, loss of employment, fear of transmitting the disease, lifestyle and emotional difficulties and problems within the provider-patient relation$\operatorname{ship}(5)$.

A great degree of negative psychological, social and physical symptoms have been reported with chronic HBV infection (6). Feelings of social isolation among hepatitis patients creates a fear of disclosing their disease to anyone $(7,8)$. Patients use terms like "leper" and "hermit" to describe their social isolation. Almost 50\% of HBV/HCVpositive patients report suffering from discrimination, which includes alienation from co-workers, family members and even from health-care providers and leads to a high perceived impact of these symptoms on quality of life (1). Job discrimination has been reported in $20 \%$ of patients, while $8 \%$ felt that medical professionals denied them services because of their hepatitis-positive status (3). In one study $41 \%$ of patients had some type of communication difficulties with their doctors (9). Fear of transmitting the disease to family members and close contacts means that hepatitis patients may choose to limit their social contacts, thus adding to their isolation and misery (2). Among the emotional problems associated with hepatitis, irritability is the most common symptom (5). Moreover, feelings of shame and worry and hesitation in discussing health problems with life partners creates a barrier to seeking health care and adopting the necessary preventive measures to avoid disease transmission (10). The media portrayal of diseases such as hepatitis, tuberculosis and sexually transmitted diseases as "bad" diseases reinforces experiences of stigma (11).

In Pakistan, the estimated prevalence of $\mathrm{HBV}$ in the population is $2.5 \%$ and of $\mathrm{HCV}$ is $4.9 \%$ (12). A recent study from Karachi reported that HCV patients had to face a number of problems which varied according to patients' education, income, societal and family background as well as the behaviour of health-care providers (13). However, few data are available that describe the experiences and stigma associated with both different types of hepatitis. The current study was planned to identify the experiences of stigma among both hepatitis B and C patients in hospitals in Islamabad and Rawalpindi, Pakistan.

\section{Methods}

\section{Study design and setting}

This was a qualitative and quantitative study conducted in outpatient departments and inpatient medical wards of 3 tertiary-care hospitals in Pakistan: the Pakistan Institute of Medical Sciences in Islamabad, the Federal Government Services Hospital (Polyclinic) in Islamabad and the Holy Family Hospital in Rawalpindi, from June 2012 to January 2013.

\section{Sampling}

Patients with confirmed HBV and/or $\mathrm{HCV}$ infection who were aged over 18 years and had been diagnosed for more than 6 months were enrolled. As this was a qualitative study, a convenience sample of 140 patients was taken. Patients with acute hepatitis, hepatitis B or C with cancer, or coma were excluded. Patients coming to outpatient departments who met the inclusion criteria were informed about the objectives of the study and, after they had given written informed consent, were interviewed in a separate room by trained researchers. For inpatients, the patients admitted to gastroenterology wards of selected hospitals were approached, briefed about the study and asked to participate. After written informed consent had been taken, interviews were conducted. The diagnosis of all cases was confirmed from their medical records.

\section{Data collection}

A total of 80 outpatients and 60 inpatients were interviewed using a pretested, semi-structured questionnaire. All interviews were done in the local language (Urdu) by trained interviewers.

The questionnaire comprised 6 sections. Section 1 collected patients' background data (i.e. age, sex, marital status, occupation, social class and type of hepatitis) and how they thought they had acquired the disease. Section 2 was about personal stigma experienced by patients (i.e. how they had found out about the disease, feelings about being HBV/HCV-positive, fear of transmitting the disease, general behaviour of people around them, feelings of loneliness and isolation). Section 3 concerned stigma from the patients' close family members (brothers, sisters, parents), other relatives (cousins) and friends (i.e. had they informed family members and friends, had family/ friends started ignoring/avoiding them, refusing to share personal belongings and avoiding eating, shaking hands or sitting with them). Section 4 was about stigma from the spouse (i.e. had they had informed spouse, what was spouse's reaction, how had it affected the marital relationship, fear of transmitting the 
disease to a child). Section 5 concerned patients' experiences of medical treatment and health-care providers (i.e. were they receiving treatment for the disease, satisfaction with treatment, had they been given information and what were health-care providers' attitude/ behaviour towards them). Section 6 was about patients' financial and job issues (i.e. were they working and if so had they informed work colleagues, had colleagues' behaviour towards them changed). Finally, for qualitative part of the study there was a blank space to record patients' experiences or feelings.

Occupation was grouped into government employee, private business worker, manual labourer or housewife. Socioeconomic status was defined based on employment, vehicle ownership and children's schooling (low = no family members permanently employed, no vehicle ownership and children studying in public school; middle $=1-2$ family members employed, motorcycle ownership and children studying in private school; high $=$ more than 2 family members employed, car ownership and children studying in private school).

A patient was defined as stigmatized if he/she experienced at least one of the following: loneliness and isolation, fear of transmission of virus, changes in the marital relationship or changes in colleagues' attitudes at work. Lifestyle change was defined as when a person experienced a change in routine activities due to weakness and behavioural changes with family, relatives and friends. Worry was defined as when a patient was anxious and troubled due to hepatitis. A stigmatizing attitude/behaviour of physicians was when patients felt that the physician was taking extra precautions or avoiding them rather than behaving as normal.

Ethical clearance was obtained from the hospital ethics review committee of the Pakistan Institute of Medical Sciences and the Federal Government Services Hospital (Polyclinic). Written consent was obtained from all patients before inclusion in the study.

\section{Data analysis}

The data were entered and analysed using SPSS, version 15. Descriptive statistics (numbers and percentages) are reported from the main survey and the differences between patients with and without stigma and between males and females were analysed by the $z$-test. Responses to open-ended questions during interviews were noted by the primary investigators. The qualitative data were analysed by the content analysis method. Transcripts were manually analysed by researchers, and texts with similar meanings were grouped into categories and subcategories after reaching a consensus. All quotations in this study are from the study participants.

\section{Results}

The demographic characteristics of the 140 study participants are shown in Table 1. A majority of respondents were males $(61 \%)$, aged $>35$ years $(72 \%)$ and of lower socioeconomic status (70\%). The great majority of patients were positive for HCV (82\%) or HBV alone (17\%); only 2 patients (1\%) reported having dual infection.

\section{Questionnaire data}

\section{Reaction to learning about disease} status

The personal assessment of patients about their disease showed that 116 patients (83\%) said they were worried when they found out they had hepatitis. A total of 104 patients (75\%) agreed that hepatitis had affected their lifestyle (Table 2). Of these, 50/105 (48\%) said that their routine activities were disturbed while 33 (31\%) felt depressed and avoided social activities and gatherings.

Two-thirds of patients (66\%) were afraid of transmitting the virus to others and 37\% felt lonely and isolated (26\% sometimes and $11 \%$ always). Among the 92 respondents who believed in viral transmission, 63 (68\%) thought that the virus could be transmitted through sharing things (towels, utensils, etc.) and 12 thought it was transmitted via blood donations, 5 by sexual intercourse and 3 from other sources. However, 9 patients reported that this could be transmitted through both sharing things and blood donations.

\section{Personal experiences of stigma}

A total of 111 patients reported experiencing at least one kind of stigma. There were no significant differences in the age, sex or other demographic characteristics of the stigma patients compared with the total sample of patients (Table 1). There were also no differences by inpatient/outpatient status or duration of illness.

\section{Relationship with relatives, friends and spouse}

The great majority of patients said they had informed their close family members (98\%), other relatives (94\%) and friends (96\%) about their disease (Table 2). When respondents were asked about the impact of the disease on their relationships $10 \%$ reported that family members, 24\% that other relatives and $9 \%$ that friends had started ignoring or avoiding them after finding out about their disease status (Table 3), although the friends and relatives of around $20 \%$ of patients became sympathetic. Almost two-thirds of patients (64\%) reported that family members felt worried and $26 \%$ that they had asked for treatment. However, $71 \%$ of patients felt that there was no change in the attitude and response of friends and of other relatives (53\%). Although some patients reported that their family members were always (7\%) or sometimes (12\%) hesitant in sharing towels, soap, eating utensils, glasses and cups, $81 \%$ of patients did not notice any changes. Patients also reported noticing that 
family and friends were hesitant about eating, shaking hands or sitting with them (Table 3).

A total of 112/125 married patients (90\%) had told their spouse about their disease status (Table 2). In about half of these cases $(57 / 112,51 \%)$ patients reported that this had affected their marital relations; $46 / 57$ (81\%) said that their spouse avoided intercourse altogether and 11 (19\%) had started using condoms. When asked to rate how much the disease affected their marital relations, $21 \%$ reported that it was very affected and $14 \%$ that it was only a little affected, while the remainder felt that they were not affected.

A total of 27 patients (22\%) reported that virus could be transmitted from mother to newborn. When they were asked about preventive measures, 20 respondents had no information, while 3 believed that this could be prevented by avoiding breastfeeding.
Only 2 patients knew that this could be prevented using family planning methods. Two patients discussed this with their treating physicians, who told them that the virus is not transmitted from mother to child.

\section{Financial and job issues}

Of the 35 employed patients, 23 were already employed while 12 had found a job after getting the diagnosis and 1 reported problems in getting a job. A

Table 1 Comparison of demographic characteristics of all patients with hepatitis B (HBV) and C virus (HCV) infection and those who experienced stigma

\begin{tabular}{|c|c|c|c|c|c|c|}
\hline \multirow[t]{2}{*}{ Patients' characteristics } & \multicolumn{2}{|c|}{$\begin{array}{c}\text { Total } \\
(n=140)\end{array}$} & \multicolumn{2}{|c|}{$\begin{array}{l}\text { Experienced stigma } \\
\qquad(n=111)\end{array}$} & \multirow[t]{2}{*}{ Z-value } & \multirow[t]{2}{*}{$P$-value } \\
\hline & No. & $\%$ & No. & $\%$ & & \\
\hline \multicolumn{7}{|l|}{ Sex } \\
\hline Male & 86 & 61 & 71 & 64 & 0.41 & 0.34 \\
\hline Female & 54 & 39 & 40 & 36 & 0.41 & 0.34 \\
\hline \multicolumn{7}{|l|}{ Age (years) } \\
\hline 18-35 & 39 & 28 & 31 & 28 & 0.01 & 0.49 \\
\hline$>35$ & 101 & 72 & 80 & 72 & 0.01 & 0.49 \\
\hline \multicolumn{7}{|l|}{ Socioeconomic status } \\
\hline Upper & 17 & 12 & 15 & 14 & 0.3 & 0.37 \\
\hline Middle & 31 & 22 & 26 & 23 & 0.24 & 0.40 \\
\hline Lower & 92 & 66 & 70 & 63 & 0.43 & 0.32 \\
\hline \multicolumn{7}{|l|}{ Marital status } \\
\hline Married & 125 & 89 & 99 & 89 & 0.02 & 0.49 \\
\hline Single & 15 & 11 & 11 & 10 & 0.02 & 0.49 \\
\hline \multicolumn{7}{|l|}{ Occupation } \\
\hline Government employee & 36 & 26 & 31 & 28 & 0.39 & 0.34 \\
\hline Labourer & 23 & 16 & 15 & 14 & 0.63 & 0.26 \\
\hline Housewife & 43 & 31 & 31 & 28 & 0.48 & 0.31 \\
\hline Private business worker & 25 & 18 & 22 & 20 & 0.39 & 0.34 \\
\hline \multicolumn{7}{|l|}{ Type of patient } \\
\hline Outpatient & 80 & 57 & 65 & 59 & 0.22 & 0.40 \\
\hline Inpatient & 60 & 43 & 46 & 41 & 0.22 & 0.40 \\
\hline \multicolumn{7}{|l|}{ Duration of illness (years) } \\
\hline$\leq 1$ & 50 & 36 & 41 & 37 & 0.20 & 0.42 \\
\hline$\leq 2$ & 19 & 14 & 17 & 15 & 0.39 & 0.34 \\
\hline$\leq 3$ & 22 & 16 & 14 & 13 & 0.69 & 0.24 \\
\hline$\leq 4$ & 10 & 7 & 10 & 9 & 0.54 & 0.29 \\
\hline$\leq 5$ & 37 & 27 & 28 & 25 & 0.21 & 0.41 \\
\hline \multicolumn{7}{|l|}{ Hepatitis status } \\
\hline $\mathrm{HCV}$ & 115 & 82 & 91 & 82 & 0.03 & 0.48 \\
\hline HBV & 23 & 17 & 19 & 17 & 0.14 & 0.44 \\
\hline Both HBV + HCV & 2 & 1 & 1 & 1 & 0.38 & 0.35 \\
\hline
\end{tabular}




\begin{tabular}{|c|c|c|c|c|c|c|c|c|}
\hline \multirow[t]{2}{*}{ Question } & \multicolumn{2}{|c|}{$\begin{array}{c}\text { Total } \\
(n=140)\end{array}$} & \multicolumn{2}{|c|}{$\begin{array}{l}\text { Female } \\
(n=54)\end{array}$} & \multicolumn{2}{|c|}{$\begin{array}{c}\text { Male } \\
(n=86)\end{array}$} & \multirow[t]{2}{*}{ z-value } & \multirow[t]{2}{*}{$\boldsymbol{P}$-value } \\
\hline & No. & $\%$ & No. & $\%$ & No. & $\%$ & & \\
\hline \multicolumn{9}{|l|}{ Personal stigma } \\
\hline Affected lifestyle & 105 & 75 & 32 & 59 & 73 & 85 & 3.41 & $<0.001$ \\
\hline Feel lonely and isolated & 52 & 37 & 26 & 48 & 26 & 30 & 2.14 & 0.02 \\
\hline Fear of transmission of virus & 93 & 66 & 35 & 65 & 58 & 67 & 0.32 & 0.37 \\
\hline \multicolumn{9}{|l|}{$\begin{array}{l}\text { Stigma from family members } \\
\text { and friends }\end{array}$} \\
\hline $\begin{array}{l}\text { Informed family members } \\
\text { (brothers, sisters, parents) }\end{array}$ & 137 & 98 & 53 & 98 & 84 & 98 & 0.19 & 0.42 \\
\hline $\begin{array}{l}\text { Family members hesitant abou } \\
\text { sharing things }(n=137)\end{array}$ & 26 & 19 & 13 & 24 & 13 & 15 & 1.33 & 0.091 \\
\hline $\begin{array}{l}\text { Informed other relatives } \\
\text { (cousins) }\end{array}$ & 131 & 94 & 50 & 93 & 81 & 94 & 0.37 & 0.36 \\
\hline Informed friends & 134 & 96 & 52 & 96 & 82 & 95 & 0.27 & 0.39 \\
\hline \multicolumn{9}{|l|}{ Stigma from spouse ${ }^{a}$} \\
\hline Informed spouse & 112 & 90 & 41 & 84 & 71 & 93 & 1.74 & 0.04 \\
\hline $\begin{array}{l}\text { Change in relationship with } \\
\text { spouse }\end{array}$ & 57 & 46 & 14 & 29 & 43 & 57 & 3.06 & 0.001 \\
\hline \multicolumn{9}{|l|}{ Stigma from health-care providers } \\
\hline Getting treatment & 115 & 82 & 38 & 70 & 77 & 90 & 2.9 & $<0.001$ \\
\hline Satisfied with treatment & 106 & 76 & 37 & 69 & 69 & 80 & 1.59 & 0.06 \\
\hline $\begin{array}{l}\text { Doctors did not provide } \\
\text { information }\end{array}$ & 79 & 56 & 28 & 52 & 51 & 59 & 0.86 & 0.19 \\
\hline $\begin{array}{l}\text { Doctors showed normal } \\
\text { attitude/behaviour }\end{array}$ & 120 & 86 & 41 & 76 & 79 & 92 & 2.62 & 0.004 \\
\hline
\end{tabular}

aPercentages of those who were married: total $n=125 ;$ women $n=49 ;$ men $n=76$.

majority $(27,77 \%)$ had informed their colleagues and 23 of them felt that there had been changes in the attitude of their colleagues. However, 8 patients did not share their disease status due to fear of bad reactions.

\section{Treatment and relationship with health-care providers}

A total of 115 patients (82\%) were receiving treatment for the disease (Table 2) and 106 of them (92\%) were satisfied with their treatment, although 56\% said that doctors did not provide additional information about the disease. When asked about the attitude/behaviour of doctors, $86 \%$ reported that it was as normal (Table 2), while $8 \%$ said that doctors took extra precautions with them, $2 \%$ felt that doctors were avoiding them and the remainder did not respond.
Comparison of experiences of male and female patients

Male patients were significantly more affected than females were in term of changes in lifestyle ( $85 \%$ versus 59\%) and changes in relationship with the spouse (64\% versus 14\%). They were also more likely to report receiving treatment (90\% versus 70\%) and that the attitude of doctors towards them was as normal (92\% versus 76\%). Significantly more females than males reported feelings of loneliness and isolation (48\% versus 30\%) (Table 2).

\section{Qualitative data}

The qualitative analysis of patients' comments showed that the experiences and feelings of patients reflected their exposure to stigma and varied from case to case. However, generally their comments showed the bitter trajectory of their life after hepatitis. The emotional disturbances due to changes in the behaviour of family members, relatives and friends were more commonly reported.

"It seems as if I am suffering from leprosy. Ifeel separated and isolated".

"I am depressed and feel lonely. I can't even sleep. Even my brothers have left me. It seems that everyone has left me. I have no interest in life."

"My family members and relatives don't want to make contact with me. They tried to avoid sharing glasses, cups and towels with me. I can't cook food in the kitchen. I am given my share of food separately in a separate place".

"My neighbours and colleagues think that this disease spreads through contact and so they avoid sharing things and even 


\begin{tabular}{|c|c|c|c|c|c|c|}
\hline \multirow[t]{2}{*}{ Question } & \multicolumn{2}{|c|}{ Family members } & \multicolumn{2}{|c|}{ Relatives } & \multicolumn{2}{|c|}{ Friends } \\
\hline & No. & $\%$ & No. & $\%$ & No. & $\%$ \\
\hline \multicolumn{7}{|c|}{$\begin{array}{l}\text { Hesitant about eating, shaking hands or sitting } \\
\text { with you? }(n=140)\end{array}$} \\
\hline Every time & 8 & 6 & 13 & 9 & 6 & 4 \\
\hline Sometimes & 21 & 15 & 19 & 14 & 14 & 10 \\
\hline Never & 111 & 79 & 108 & 77 & 120 & 86 \\
\hline \multicolumn{7}{|c|}{$\begin{array}{l}\text { Response of family after finding out about } \\
\text { your disease? }(n=137)\end{array}$} \\
\hline Worried & 88 & 64 & - & - & - & - \\
\hline Asked for treatment & 35 & 26 & - & - & - & - \\
\hline Started ignoring & 14 & 10 & - & - & - & - \\
\hline \multicolumn{7}{|c|}{$\begin{array}{l}\text { Response of relatives }(n=131) \text { and friends }(n=134) \\
\text { after finding out about your disease? }\end{array}$} \\
\hline Same as before & - & - & 70 & 53 & 95 & 71 \\
\hline Sympathetic & - & - & 29 & 22 & 27 & 20 \\
\hline Started ignoring & - & - & 32 & 24 & 12 & 9 \\
\hline
\end{tabular}

eating and sitting with me. My family members even avoid sharing towels."

"My friends and relatives talk about my disease in a negative sense. I have separated my eating utensils, cup and glass. I personally feel that I have done something wrong."

The impact of the disease on marital relations was also severe and had complicated the family life of patients. The statements of a few patients were bitter.

"I feel depressed by the behaviour of my husband. He is avoiding sexual relations with me and is even reluctant to share eating utensils and other things. He is also hesitant about sitting and living with me. I want to end my life".

"My wife had been avoiding me since diagnosis of this disease. She even tried to keep my 7-year-old daughter away from me. I don't want to live anymore".

One woman said "I was engaged. When my fiancé and his family members found out that I am suffering from hepatitis $C$, they broke off the relationship. I was so worried and depressed about this attitude. This was unbearable for me. Since diagnosis there have been no proposals for me from my relatives because of this disease. Now I am engaged to someone outside my family but we have not told them that I am hepatitis $C$ positive. I am afraid that if I told them the same incident may be repeated again".

Similarly, financial difficulties and discrimination at the workplace was also reported. Most of the patients had lost their jobs due to fatigue and weakness, some had been dismissed from their duties, some faced poor attitudes of colleagues and many faced difficulty in getting a job.

"I was a rickshaw driver, but due to hepatitis C, I became so weak that I could not work properly and to meet treatment costs I had to sell my rickshaw. My relatives have a bad attitude with me and nobody helped me".

"When my boss and colleagues found out that I have this disease, they have not only kicked me out but not even contacted me or talked to me. It was a hating attitude and I felt really very depressed".

"I was working in a hotel and applied for a job in the army as a cook. During the medical examination I found out that I was hepatitis $C$ positive. They refused to take me, and when I asked the reason the staff said, 'You cannot join the army even as a sweeper' because of this disease. When the hotel (where I worked) knew that I had this disease, they fired me from the job. I was really tense and worried at that time and remained bedridden for 10 days".

"I wanted to go abroad for work but due to hepatitis I was declared medically unfit. Now I cannot get a job abroad or here in my country. I am extremely worried about my future. I feel that I can work but they don't give me a job".

"I was a daily wage labourer. For 6 months I have not done any work due to my illness. I am very worried".

\section{Discussion}

Analysis of the interviews has shown that HBV-and HCV-positive patients have to face difficulties in their routine life and that there are various types of stigmas that are attached to them. Marital relationships were strongly affected by the disease and in the present study; nearly half of married patients (51\%) reported changes in their spousal relationship, and in the majority of cases spouses were avoiding sexual relations after hepatitis. The percentage reporting avoidance of sexual intercourse 
from another study in Pakistan and a study in the United States were 27\% and $17 \%$ respectively $(14,15)$. A study describing social stigma in HCV-positive women concluded that women were concerned about sexual transmission, pregnancy and child care affecting their close relationships and their expected gender role (16). Although the literature shows a low risk of sexual transmission in intrafamilial relations (17) misconceptions of disease spread via sexual relationships with a partner is still prevalent in societies. There is a need to improve the level of awareness among the public about modes of transmission, especially for hepatitis-positive couples, as this may reduce their worries and help avoid difficulties in marital relationships.

Changes in lifestyle were reported by $75 \%$ of participants in the current study. This was either due to weakness (fatigue) or emotional disturbances (mood swings, anxiety, irritability, depression, etc.), which is consistent with previous reports $(18,19)$. Change in patients' daily life has been attributed to worries and uncertainties associated with hepatitis due to its slow and silent nature as well as a lack of proper information about its transmission, prognosis and treatment (20). Similarly, a fear of transmitting infection to others by sharing things such as eating utensils, cups, glasses and towels was expressed by $68 \%$ of our cases, indicating poor knowledge about transmission of $\mathrm{HBV} / \mathrm{HCV}$. Similar findings were reported in other studies $(14,16,21)$.

Stigma from health-care providers was reported by few patients in the present study, which contrast with the findings of some other studies $(11,22)$. On the other hand, almost half of patients thought that doctors did not provide information about the disease.
A diagnosis of hepatitis $\mathrm{B}$ and $\mathrm{C}$ is an opportunity for health-care providers to create awareness about the disease and to encourage patients in their commitment to treatment and self-care.

Stigma related to hepatitis occurs in both sexes; however, female patients have been reported as more concerned with family and social relations, sexual transmission and pregnancy and child care as compared with males and this concern affects their relationships and ability to fulfil their gender roles (16). When the experiences of male and female patients were compared in our study, males were more affected than females were in term of changes in lifestyle, fear of disease transmission and changes in relationship with the spouse. In contrast, more females than males reported feelings of loneliness and isolation.

The findings of the open-ended questions revealed that a majority of patients had bitter experiences in their routine life. The behaviour of family members or friends has been reported to result in feelings of depression and isolation (23) and it was also reported previously by patients in Karachi, Pakistan, that they faced difficulties from their family member resulting in increased suffering (13). Breakup of relationships with spouses or fiancés were noted in this study and were also reported in a study from the United States (15). Similarly, the financial pressure was also immense, due either to poor attitudes of employers and colleagues or to physical inability to accomplish tasks properly. It was noted that some patients reported being badly affected by knowledge of their disease, by the loss of a job or inability to obtain a visa to travel. This needs to be improved and, if someone is found to be positive during screening, there should be proper counselling and mechanisms to guide them.

The overall assessment showed that experiences of stigma varied depending on the patient's situation. However, these findings indicate that $\mathrm{HBC} / \mathrm{HCV}$ patients face discrimination in every walk of life, including breakage in interand intrafamilial relations, financial constraints due to loss of job or problems in getting a new job.

This was a hospital-based study conducted on patients presenting at the same locality, and therefore these findings could not be generalized.

\section{Conclusions}

Hepatitis B and C patients experience emotional disturbances due to knowledge about their disease status and its associated stigma leading to changes in their lifestyles. The stigmatization is mostly due to ignorance and lack of awareness about the mode of disease transmission among patients and their family members. Educational interventions are needed to overcome such misconceptions.

\section{Acknowledgements}

We would like to thank Professor Tashfeen Adam, Department of Gastroenterology, Pakistan Institute of Medical Sciences, Professor Muhammad Umar, Holy Family Hospital, and Dr Iftikhar Naru and Dr Iftikhar Ahmed Malik, Federal Government Services Hospital. We are also thankful to Mr Rizwan Ullah for data analysis.

Funding: We acknowledge the Pakistan Medical Research Council for providing the funds.

Competing interests: None declared.

\section{References}

1. Silberbogen AK, Ulloa EW, Janke EA, Mori DL. Psychosocial issues and mental health treatment recommendations for patients with hepatitis C. Psychosomatics. 2009 MarApr;50(2):114-22. PMID:19377019
2. Zickmund S, Ho EY, Masuda M, Ippolito L, LaBrecque DR. "They treated me like a leper". Stigmatization and the quality of life of patients with hepatitis C. J Gen Intern Med. 2003 Oct;18(10):835-44. PMID:14521647 
3. Porter LK. A guide to: stigma and hepatitis C. HPSC guides [Internet]. Sacramento (CA): HCV Advocate; 2008. (http://www. hcvadvocate.org/hepatitis\%5Cfactsheets_pdf/Stigma\%20 Guide.pdf, accessed 16 August 2014).

4. Link BG, Phelan JC. Conaceptualizing stigma. Annu Rev Sociol. 2001;27:363-85.

5. Zickmund SL. Psychosocial issues and HCV. In: Mental health and hepatitis $C$ caring. Chapter 21, Section 4. 4th ed. Oregon City (OR): Caring Ambassadors Program Inc; 2008 (http://hepcchallenge.org/wp-content/uploads/2014/04/ Hepatitis_C_Choices_4thEdition.pdf, accessed 16 August 2014).

6. Spiegel BM, Bolus R, Han S, Tong M, Esrailian E, Talley J, et al. Development and validation of a disease-targeted quality of life instrument in chronic hepatitis B: the hepatitis B quality of life instrument, version 1.0. Hepatology. 2007 Jul;46(1):113-21. PMID:17596882

7. Janke EA, McGraw S, Fraenkel L, Garcia-Tsao G. Psychosocial correlates of hepatitis $\mathrm{C}$ : interaction and impact on quality of life. Psychosomatics. 2008;49(6):494-501. PMID:19122126

8. O'Brien AP, Cross WM, Higgs P, Munro I, Bloomer MJ, Chou KR. Australians living with and managing hepatitis C. Issues Ment Health Nurs. 2010 Aug;31(8):520-4. PMID:20624020

9. McCreaddie M, Lyons I, Horsburgh D, Miller M, Frew J. The isolating and insulating effects of hepatitis $C$ : a substantive grounded theory. Gastroenterol Nurs. 2011 JanFeb;34(1):49-59. PMID:21301264

10. Attitudes about hepatitis $\mathrm{C}$ education campaign for people newly diagnosed with hepatitis C. Boston (MA): Market Street Research Inc. and Policy Studies Inc. for Massachusetts Department of Public Health; 2001 (http://www.heart-intl.net/ HEART/100405/AttitudesaboutHCVEducation.pdf (accessed on 22 September 2014).

11. Smith R. Media depictions of health topics: challenge and stigma formats. J Health Commun. 2007 Apr-May;12(3):233-49. PMID:17497378

12. Ali SA, Donahue RMJ, Qureshi H, Vermund SH. Hepatitis B and hepatitis $C$ in Pakistan: prevalence and risk factors. Int J Infect Dis. 2009 Jan;13(1):9-19. PMID:18835208

13. Jiwani NS, Gul RB, Ali A, Salih M, Hanzala M. Experiences and perceptions of patients living with hepatitis $C$ in Karachi, Pakistan. J Transcult Nurs. 2013 Jul;24(3):297-304. PMID:23765566
14. Qureshi H, Bile KM, Jooma R, Alam SE, Afridi HU. Prevalence of hepatitis $B$ and $C$ viral infections in Pakistan: findings of a national survey appealing for effective prevention and control measures. East Mediterr Health J. 2010;16 Suppl:S15-23. PMID:21495584

15. Blasiole JA, Shinkunas L, Labrecque DR, Arnold RM, Zickmund SL. Mental and physical symptoms associated with lower social support for patients with hepatitis C. World J Gastroenterol. 2006 Aug 7;12(29):4665-72. PMID:16937437

16. Grundy G, Beeching N. Understanding social stigma in women with hepatitis C. Nurs Stand. 2004 Oct 6-12;19(4):35-9. PMID:15521414

17. Zacks S, Beavers K, Theodore D, Dougherty K, Batey B, Shumaker J, et al. Social stigmatization and hepatitis $\mathrm{C}$ virus infection. J Clin Gastroenterol. 2006 Mar;40(3):220-4. PMID:16633123

18. Brusaferro S, Barbone F, Andrian P, Brianti G, Ciccone L, Furlan A, et al. A study on the role of the family and other risk factors in HCV transmission. Eur J Epidemiol. 1999 Feb;15(2):125-32. PMID:10204641

19. Hilsabeck RC, Hassanein TI, Perry W. Biopsychosocial predictors of fatigue in chronic hepatitis C. J Psychosom Res. 2005 Feb;58(2):173-8. PMID:15820845

20. Teston EF1, Silva RL, Marcon SS. Living with hepatitis: impact on the daily life of infected subjects. Rev Esc Enferm USP. 2013Aug;47(4):860-8. PMID:24310683.

21. Lang CA, Conrad S, Garrett L, Battistutta D, Cooksley WG, Dunne MP, et al. Symptom prevalence and clustering of symptoms in people living with chronic hepatitis $C$ infection. J Pain Symptom Manage. 2006 Apr;31(4):335-44. PMID:16632081

22. Zickmund S, Hillis SL, Barnett MJ, Ippolito L, LaBrecque DR. Hepatitis $C$ virus-infected patients report communication problems with physicians. Hepatology. 2004 Apr;39(4):9991007. PMID:15057904

23. Conrad S, Garrett LE, Cooksley WGE, Dunne MP, MacDonald GA. Living with chronic hepatitis $C$ means 'you just haven't got a normal life any more'. Chronic Illn. 2006 Jun;2(2):121-31. PMID:17175655 